\title{
Influence of Tree Age and Variety on Allometric Characteristics and Water Use of Mangifera indica L. Growing in Plantation
}

\author{
Philip G. Oguntunde, ${ }^{1,2}$ Johnson T. Fasinmirin, ${ }^{1}$ and Nick van de Giesen ${ }^{2}$ \\ ${ }^{1}$ Department of Agricultural Engineering, The Federal University of Technology, Akure, Akure, Nigeria \\ ${ }^{2}$ Department of Water Management, Delft University of Technology, P.O. Box 5048, 2600 GA Delft, The Netherlands
}

Correspondence should be addressed to Philip G. Oguntunde, poguntunde@yahoo.com

Received 28 July 2011; Accepted 22 September 2011

Academic Editor: Guang Sheng Zhou

Copyright (C) 2011 Philip G. Oguntunde et al. This is an open access article distributed under the Creative Commons Attribution License, which permits unrestricted use, distribution, and reproduction in any medium, provided the original work is properly cited.

\begin{abstract}
Data on water relations and growth characteristics of mango trees needed for productive plantation management are currently lacking in West Africa. Relationships between allometric properties and water use in mango trees were examined. In addition, the effects on allometric characteristics and xylem sap flow were investigated in a mixed varieties plantation. Tree age explained more than $92 \%$ of the variation in stem diameter, over $96 \%$ of the variation in height, over $92 \%$ of the variation in crown diameter, and more than $97 \%$ of the variation in leaf area index of the 60 mango trees sampled. Water use increased from $1.01 \mathrm{~kg} \mathrm{~d}^{-1}$ to $156.7 \mathrm{~kg} \mathrm{~d}^{-1}$ from the 2- to the 33-year-old trees for a typical bright day. Sap flow was highly correlated with age under different sky conditions. A power function relating daily sap flow to age yielded an $r^{2}$ of 0.98 for bright days and 0.87 when combined with rainy day data. The water use and growth parameters of the three cultivars were generally not significantly different. This paper has implications for mango productivity and for orchard water management in potentially dry areas of West Africa.
\end{abstract}

\section{Introduction}

Mango (Mangifera indica L.), a diffuse-porous species and one of the most important tropical tree crops [1], belongs to the family Anacardiaceae [2]. It is believed that mango was brought from Arabia to Africa in the first millennium AD [3]. Ghana received more than a dozen cultivars in the early 1920 s and more than a dozen other cultivars were brought in later from Florida and India [2]. However, because of identification problems, an effort was initiated in 1967 to classify the seedlings in the Ejura district, the Ejura Agricultural Station, and the plantation of the Faculty of Agriculture, University of Science and Technology, Kumasi, in order to eliminate confusions and have identifiable cultivars marked for future research. There is great potential for the rapid growth of mango industry in West Africa if the current planting rate and government encouragements are sustained.

Although mango is drought tolerant and could be conveniently cropped under rain-fed conditions, supplemental irrigation may be required for optimising growth, fruit set, and yield [4]. Poor and unreliable flowering is one of the factors leading to low productivity [5], but applying irrigation from peak flowering to fruit maturity could induce reliable flowering leading to high yield $[6,7]$. Preflowering irrigation was reported to increase the overall photosynthetic activity of the tree at the time of flowering [8]. The necessity to directly and continuously monitor water use for precise irrigation scheduling in mango plantations has been reported $[4,7]$. Subsequently, a Granier sap flow measurement method was evaluated and applied successfully to measure sap flow per unit sapwood area in young to mature mango trees. Despite current advances, especially in Australia, there is little or no information regarding water use of mango trees in West Africa. In the study area, the planting practices have resulted in age differences of adjacent plantations coupled with indiscriminate mixtures of varieties or cultivars. These lead to differences in cultivars composition on different stands. Previous studies reported that young/mature trees use more water per unit sapwood area than old trees of the same species in a similar environment due to changes in stem and branch hydraulics with age $[9,10]$ as well as pressure gradient due to gravity [11]. The objectives of this study were 
to examine the degree to which differences in tree age and variety mixture affect water use and allometric characteristics of mango trees under subhumid tropical environment of West Africa. The study was part of the just concluded GLOWA Volta project (http://www.glowa-volta.de/), which lasted between 2000 and 2009. In the context of this project, designed to study "sustainable water use under various land use change and rainfall reliability," understanding the hydrological process in the basin water balance is very important. Determinations of water use from each component of ecosystem vegetation were required and therefore partly motivated this study.

\section{Materials and Methods}

2.1. Study Sites. Measurements took place at two sites. The age group experiment was located in the plantation (site I) of the Faculty of Agriculture, Kwami Nkrumah University of Science and Technology (KNUST) mango orchard in Ejura $\left(07^{\circ} 23^{\prime} \mathrm{N}, 01^{\circ} 21^{\prime} \mathrm{W}\right.$; elevation $\left.\approx 230 \mathrm{~m}\right)$. Stands of different age are located adjacent to one another with trees tagged with planting dates and varieties. The variety experiment was conducted in a 2.43 ha (site II) of 5-year-old mango trees of cv. Palmer, Haden, and Keitt located close to the summit of Kotokosu watershed, $15 \mathrm{~km}$ east of Ejura, Ghana $\left(07^{\circ} 20^{\prime} \mathrm{N}\right.$, $01^{\circ} 16^{\prime} \mathrm{W}$; elevation $\approx 210 \mathrm{~m}$ ). Both locations lie in the forestsavannah transition zone with loamy sand soils of generally similar properties (Table 1). The study area is characterized by distinct wet and dry seasons with long-term mean annual rainfall greater than $1.26 \mathrm{~m} \mathrm{[12].}$

2.2. Allometric Measurements. Allometric properties such as stem diameter (SD), tree height $(\mathrm{TH})$, crown diameter (CD), and leaf area index (LAI) were measured on ten randomly selected trees of six different age groups: 2-, 4-, 8-, 11-, 17-, and 33-year-old. Stem diameter (at $0.5 \mathrm{~m}$ ) was measured with a diameter tape. Tree height and crown diameter were measured with a Spiegel relaskop (Relaskop-Technik, Austria). LAI was measured at eight points under the canopy of the individual selected trees with a SunScan canopy analysis system (Delta-T Devices, Cambridge, UK). Mean value was computed by averaging all individual estimates of LAI. Sapwood thickness was measured with a core sampler and used to compute tree sapwood area (SWA). The measurements described above were also conducted on a 5-year-old mixed plantation at site II. Fifteen trees were sampled per variety.

2.3. Sap Flow and Soil Water Measurements. Sap flow was measured with the "temperature difference method" of Granier [13]. Two $2 \mathrm{~cm}$ long (heating zone) cylindrical probes, $2 \mathrm{~mm}$ in diameter, were implanted in the sapwood of the tree trunks with previously installed aluminium tubes, with a vertical separation of $12 \mathrm{~cm}$. The probes were installed on the north side of the trees to minimise direct heating from sunshine, and then shielded with aluminium foil against rainfall. The downstream probe (the upper coil) was continuously heated with a constant power source while the unheated upstream probe (the lower coil) served as a temperature reference. During conditions of zero sap flow, the
TABLE 1: Soil properties at the two study sites in Ejura district, Ghana.

\begin{tabular}{lcc}
\hline Soil property & Site I & Site II \\
\hline Sand (\%) & 82.4 & 80.4 \\
Silt (\%) & 14.3 & 12.3 \\
Clay (\%) & 3.3 & 7.3 \\
Bulk density $\left(\mathrm{g} \mathrm{cm}^{-3}\right)$ & 1.56 & 1.73 \\
pH & 5.13 & 4.64 \\
CEC (Ag+) & 4.15 & 3.82 \\
\hline
\end{tabular}

temperature difference between the lower and the upper probes represents the steady-state temperature difference caused by the dissipation of heat into nontransporting sapwood.

The age group experiment was conducted between DOY 282 and DOY 292, 2002. Sap flow was measured in six mango trees of different age. The stem diameter, bark thickness, and sapwood area of the different groups (respective) are presented in Table 2(a). Similarly, the variety experiment was conducted on young mango trees cv. Palmer, Haden, and Keitt (Table 2(b)) between DOY 261 and DOY 275, and DOY 310 and DOY 315. Profile soil water content was measured on 4 days (DOY 271, 276, 285, and 308) during the periods of sap flow measurements. A Delta-T PR1/6 capacitance probe (Delta-T Devices, Cambridge, England) was used in access tubes located within the plantations at both sites. Four sensors were arranged at $10 \mathrm{~cm}$ depth intervals down to $40 \mathrm{~cm}$ whereas one was placed at $60 \mathrm{~cm}$ and the last one at $100 \mathrm{~cm}$. Average profile soil moisture was estimated over the six sensors in the column ( $1 \mathrm{~m}$ deep) using the calibration curve supplied by the manufacturer.

2.4. Data Analysis. Sap flux density was computed with the empirical relationship validated for different species $[7,12-$ 14] as follow:

$$
F_{d}=42.84\left(\frac{\Delta T_{\max }-\Delta T}{\Delta T}\right)^{1.231}
$$

where $F_{d}$ is sap flux density integrated over the probe's length $\left(\mathrm{g} \mathrm{cm}^{-2} \mathrm{~h}^{-1}\right), \Delta T$ is the temperature difference observed between the heated and reference needles, and $\Delta T_{\max }$ is the value of $\Delta T$ when sap flow is zero, which is generally taken as the peak nighttime value of $\Delta T$. Sap flux density $\left(F_{d}\right.$, $\mathrm{g} \mathrm{cm}^{-2} \mathrm{~h}^{-1}$ ), expressed on a sapwood area basis, was converted to sap flow $\left(F, \mathrm{~kg} \mathrm{~h}^{-1}\right)$ by multiplying with SWA. Estimates were scaled up based on specific corrections proposed for mango trees [1]. Total flow was calculated from flow in the outer $2 \mathrm{~cm}$ of sapwood by assuming that flux density at depths, $x$, greater than $2 \mathrm{~cm}$ is linearly related to depth as $F_{d}(a+b x)$. The multiplier $(M)$ to convert the flow in the outer $2 \mathrm{~cm}$ of sapwood to total flow was computed as follow:

$$
\begin{gathered}
M=\frac{(Z+2 R-2)}{(2 R-2)}, \\
Z=a\left(\frac{R^{2}}{2}-2 R+2\right)+b\left(\frac{R^{3}}{6}-2 R+\frac{8}{3}\right),
\end{gathered}
$$


TABLE 2: Stem diameter (SD), bark thickness (BT), basal area (BA), and sapwood area (SWA) of the six gauged mango trees of different age group and three gauged mango trees of different variety.

(a) Age group experiment, site I.

\begin{tabular}{|c|c|c|c|c|c|}
\hline Age (years) & Variety & $\mathrm{SD}(\mathrm{cm})$ & $\mathrm{BT}(\mathrm{cm})$ & $\mathrm{BA}\left(\mathrm{cm}^{2}\right)$ & ${ }^{\#} \mathrm{SWA}\left(\mathrm{cm}^{2}\right)$ \\
\hline 2 & Palmer & 3.9 & 0.2 & 11.9 & 9.2 \\
\hline 4 & Palmer & 11.3 & 0.5 & 100.3 & 83.3 \\
\hline 8 & Palmer & 17.2 & 1.2 & 232.4 & 171.5 \\
\hline 11 & Palmer & 34.5 & 1.4 & 934.8 & 559.6 \\
\hline 17 & Palmer & 56.2 & 1.2 & 2480.6 & 927.2 \\
\hline 33 & Palmer & 66.0 & 2.0 & 3421.2 & 1071.3 \\
\hline
\end{tabular}

(b) Variety group experiment, site II.

\begin{tabular}{lccccc}
\hline Age (years) & Variety & SD $(\mathrm{cm})$ & BT $(\mathrm{cm})$ & BA $\left(\mathrm{cm}^{2}\right)$ & ${ }^{\#}$ SWA $\left(\mathrm{cm}^{2}\right)$ \\
\hline 5 & Palmer & 11.5 & 0.5 & 103.0 & 85.4 \\
5 & Haden & 12.2 & 0.8 & 116.9 & 86.2 \\
5 & Keitt & 12.0 & 0.8 & 113.1 & 84.2 \\
\hline
\end{tabular}

${ }^{\#}$ SWA for trees $>4$ years old is estimated with procedure outline in Lu et al. [1].

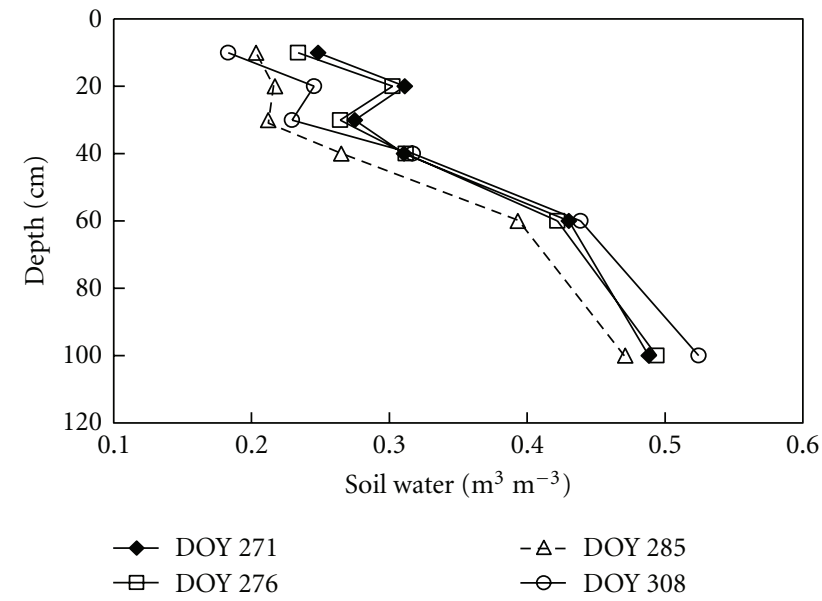

(a)

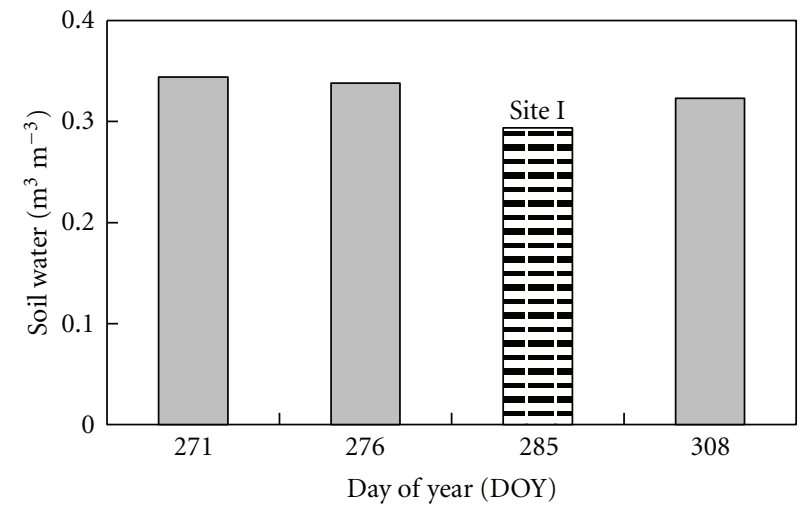

(b)

FIGURE 1: Soil water status during the sap flow measurement. (a) Profile pattern for DOY 285 (site I) and other dates (site II) and (b) average soil moisture in the $1 \mathrm{~m}$ column.

where $a$ and $b$ are fitted coefficients and $R$ is the stem radius after removing bark thickness. The values of $a$ and $b$ of $\mathrm{Lu}$ et al. [1] were used and the results compared to the estimated sap flow based on measured SWA for trees with actual SWA measurements. ANOVA and the Bonferroni mean separation test were used to compare the means of all the allometric parameters, $F_{d}$ and $F$ for different age group and variety. Nonlinear least squares regression models were explored to find possible relationships between the respective allometric parameters $(Y)$ and tree age $(X)$. Power and logarithmic functions of the form

$$
\begin{gathered}
Y=A X^{B} \\
Y=A \ln (X)+B
\end{gathered}
$$

were found to adequately describe these relationships, where $A$ and $B$ are the fitted coefficients.

\section{Results}

3.1. Soil Water Status. Figure 1(a) shows the variations in the volumetric soil water content up to a depth of $1 \mathrm{~m}$. The selected days were typical for the period of the experiment. Figure 1(b) shows the variation in mean water content for the same days. An average of $0.29 \mathrm{~m}^{3} \mathrm{~m}^{-3}$ was observed on DOY 285 at site I, whereas average water content varied from $0.32 \mathrm{~m}^{3} \mathrm{~m}^{-3}$ (DOY 308) to $0.34 \mathrm{~m}^{3} \mathrm{~m}^{-3}$ (DOY 271) during the sap flow measurement period at site II. Although the observed values tend to slightly decreased with increasing DOY, no significant difference was observed in the mean daily water content for the four days $(P>0.05)$. The relative high values of soil moisture may suggest that soil water was not limiting tree transpiration during the study period.

3.2. Age and Variety Effects on Allometric Characteristics. Table 3(a) lists means and standard deviations of all the biometric parameters of the six age groups examined. Stem 
TABLe 3: Age/variety ${ }^{+}$, stem diameter (SD), tree height (TH), crown diameter (CD), and leaf area index (LAI) of mango trees at both sites in Ghana.

(a) Age group experiment, site I $(N=10$ trees per age).

\begin{tabular}{lcccc}
\hline Age/variety & $\mathrm{SD}(\mathrm{cm})$ & $\mathrm{TH}^{\#}(\mathrm{~m})$ & $\mathrm{CD}(\mathrm{m})$ & $\mathrm{LAI}^{\#}\left(\mathrm{~m}^{2} \mathrm{~m}^{-2}\right)$ \\
\hline 2 & $4.26 \pm 0.99$ & $1.73 \pm 0.55$ & $1.10 \pm 0.16$ & $1.70 \pm 0.40^{\mathrm{D}}$ \\
4 & $11.20 \pm 0.80$ & $4.06 \pm 0.27$ & $3.62 \pm 0.64$ & $2.77 \pm 0.32^{\mathrm{CD}}$ \\
8 & $19.59 \pm 2.13$ & $6.60 \pm 0.54$ & $5.36 \pm 0.63$ & $4.25 \pm 1.17^{\mathrm{C}}$ \\
11 & $36.39 \pm 1.74$ & $8.60 \pm 0.53$ & $9.47 \pm 0.94$ & $4.79 \pm 0.99^{\mathrm{BC}}$ \\
17 & $55.87 \pm 3.50$ & $9.89 \pm 0.57$ & $12.25 \pm 0.75$ & $6.29 \pm 1.46^{\mathrm{B}}$ \\
33 & $70.10 \pm 6.69$ & $14.64 \pm 0.61$ & $14.60 \pm 1.90$ & $8.40 \pm 0.91^{\mathrm{A}}$ \\
Sig. level & $P<0.001$ & $P<0.001$ & $P<0.001$ & $P<0.001$ \\
\hline
\end{tabular}

(b) Variety group experiment, site II $(N=15$ trees per cultivar).

\begin{tabular}{lcccc}
\hline Age/variety & $\mathrm{SD}(\mathrm{cm})$ & $\mathrm{TH}^{\#}(\mathrm{~m})$ & $\mathrm{CD}(\mathrm{m})$ & $\mathrm{LAI}^{\#}\left(\mathrm{~m}^{2} \mathrm{~m}^{-2}\right)$ \\
\hline Palmer & $11.74 \pm 1.77$ & $3.62 \pm 0.30^{\mathrm{B}}$ & $3.59 \pm 0.60$ & $3.31 \pm 0.45$ \\
Haden & $11.76 \pm 1.08$ & $4.13 \pm 0.22^{\mathrm{A}}$ & $3.48 \pm 0.49$ & $3.88 \pm 1.10$ \\
Keitt & $11.29 \pm 1.33$ & $3.63 \pm 0.35^{\mathrm{B}}$ & $3.71 \pm 0.42$ & $3.66 \pm 0.75$ \\
Sig. level & $P>0.05$ & $P<0.01$ & $P>0.05$ & $P>0.05$ \\
\hline
\end{tabular}

${ }^{+}$Age experiment was conducted with Palmer while variety experiment was on 5-year-old trees. "Value with different superscripted capital letters denotes significant difference using Bonferroni mean separation test (applicable to LAI in age group, where other parameters are all significantly different and TH in variety experiment where other parameters were not statistically different).

diameter showed the highest coefficient of variation (CV) of $23 \%$ in the 2 -year-old trees (mean $=4.26 \mathrm{~cm}$ ) and the lowest $\mathrm{CV}$ of $5 \%$ in the 11-year-old trees $($ mean $=36.39 \mathrm{~cm})$. The mean SD in the 33-year-old trees was $70.1 \mathrm{~cm}$ with $\mathrm{CV}$ of $10 \%$. Between the six age groups investigated, SD was significantly different $(P<0.001)$. Two regression equations (3) were fitted to relate SD with tree age. The regression constants and coefficients of determination are presented in Table 4. The $r^{2}$ values of 0.965 and 0.925 were obtained for power and logarithmic functions, respectively. High $r^{2}$ values of both models indicated a strong association between stem diameter and tree age. However, the power function that passed through the origin showed a better fit and reflected the growth process is preferred.

Tree height $(\mathrm{TH})$ increased with age from $1.73 \mathrm{~m}(\mathrm{CV}=$ $23 \%)$ to $14.64 \mathrm{~m}(\mathrm{CV}=4 \%)$ in 2-year-old and 33-year-old trees, respectively. Similar to SD, TH was also significantly different among all the age groups. The two regression models applied to relate TH and tree age yielded $r^{2}$ values of 0.961 and 0.976 , respectively. Crown diameter (CD) varied form $1.10 \pm 0.16 \mathrm{~m}$ to $14.60 \pm 1.90 \mathrm{~m}$ in the youngest and oldest tree groups. The highest CV of $18 \%$ was found with the 4 -year-old trees and the lowest CV of $6 \%$ was found with the 17-year-old trees. The fitted models indicated strong association between age and CD with $r^{2}$ of 0.927 and 0.956 , respectively. Leaf area index increased with tree age and varied from $1.7 \pm 0.40 \mathrm{~m}^{2} \mathrm{~m}^{-2}$ to $8.40 \pm 0.91 \mathrm{~m}^{2} \mathrm{~m}^{-2}$. The association between LAI and tree age based on a power function, yielded $r^{2}$ value of 0.992 compared to $r^{2}$ value of 0.972 for the logarithmic function. Unlike other listed allometric characteristics, LAI of 2- and 4-year-old group, 8 and 11 and 11 , and 17 year olds were not significantly different $(P>0.5$, Table 3(a)).
Stem diameter, TH and LAI in Haden were slightly higher than in Keitt and Palmer (Table 3(b)). The differences were not significant for SD, CD, and LAI. However, TH differences between Haden and Keitt or Palmer were significant $(P<$ 0.05 ). LAI was about $17 \%$ higher in Haden (LAI $=3.88 \pm$ $1.10 \mathrm{~m}^{2} \mathrm{~m}^{-2}$ ) and $13 \%$ higher in Keitt (LAI $=3.66 \pm$ $\left.0.75 \mathrm{~m}^{2} \mathrm{~m}^{-2}\right)$ than in Palmer $\left(\mathrm{LAI}=3.31 \pm 0.45 \mathrm{~m}^{2} \mathrm{~m}^{-2}\right)$ trees. Combining the data for the three cultivars, cross-correlation of the allometric parameters showed that CD highly correlates with SD $(P=0.005)$, and less correlated with LAI $(P=0.043)$.

3.3. Age and Variety Effects on Tree Water Use. Diurnal variations in sap flux density $\left(F_{d}\right)$ and total sap flow $(F)$ for a typical bright and a typical rainy day are shown in Figures 2(a)-2(d). Peak daytime $F_{d}$ values of $15.7 \mathrm{~g} \mathrm{~cm}^{-2} \mathrm{~h}^{-1}$ and $15.4 \mathrm{~g} \mathrm{~cm}^{-2} \mathrm{~h}^{-1}$ were measured in the trunk of the 2- and 4year-old trees, respectively. Both $17-$ and 33-year-old trees showed peak values near $11.0 \mathrm{~g} \mathrm{~cm}^{-2} \mathrm{~h}^{-1}$. However, unlike the $F_{d}$, the diurnal course of $F$ showed clear differences between age groups. Water use increased with tree age with the 33 -year-old tree showing a peak value of $21 \mathrm{~kg} \mathrm{~h}^{-1}$ while the 2-year-old tree recorded a peak $F$ value of $0.15 \mathrm{~kg} \mathrm{~h}^{-1}$.

On a typical rainy day (Figures 2(c) and 2(d)), the diurnal pattern was not similar to the bright day. The heavy rainfall between 11.30 and 15.30 lowered the values of $F_{d}$ and $F$, leading to two peaked during the diurnal course. The youngest of the gauged mango trees recorded the highest maximum $F_{d}$ value of $9 \mathrm{~g} \mathrm{~cm}^{-2} \mathrm{~h}^{-1}$ as compared to $6.6 \mathrm{~g} \mathrm{~cm}^{-2} \mathrm{~h}^{-1}$ recorded in the trunk of the most mature tree. The daytime maximum $F$ values similarly showed a positive correlation with age. The youngest tree transpires with a $0.08 \mathrm{~kg} \mathrm{~h}^{-1}$ peak value whereas a value of $12.7 \mathrm{~kg} \mathrm{~h}^{-1}$ was observed in the oldest tree. 


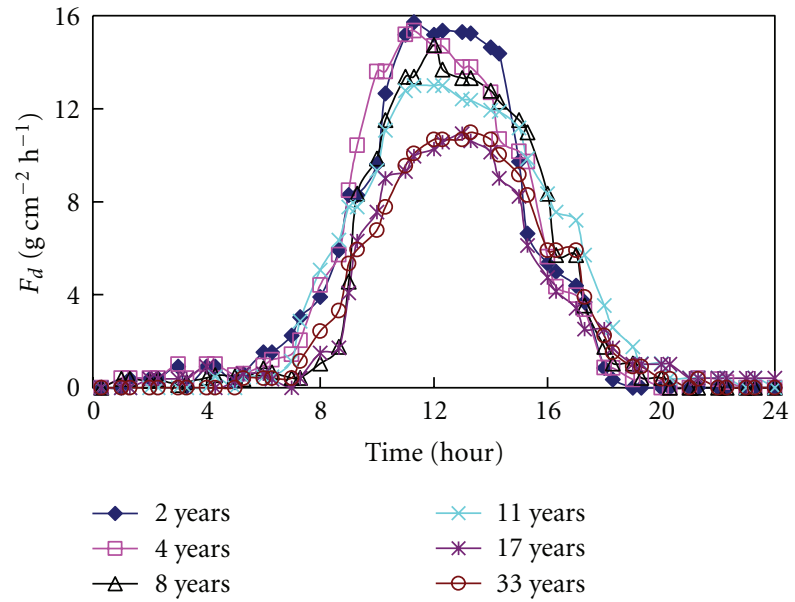

(a)

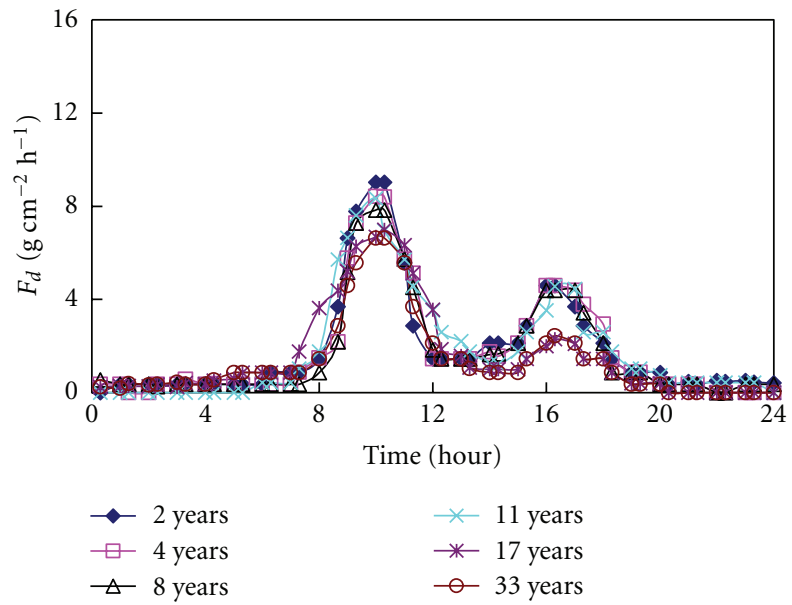

(c)

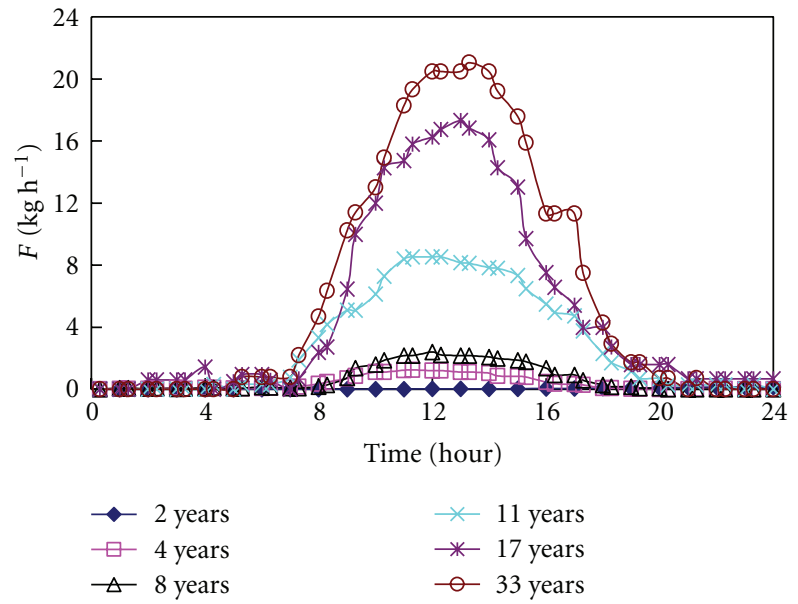

(b)

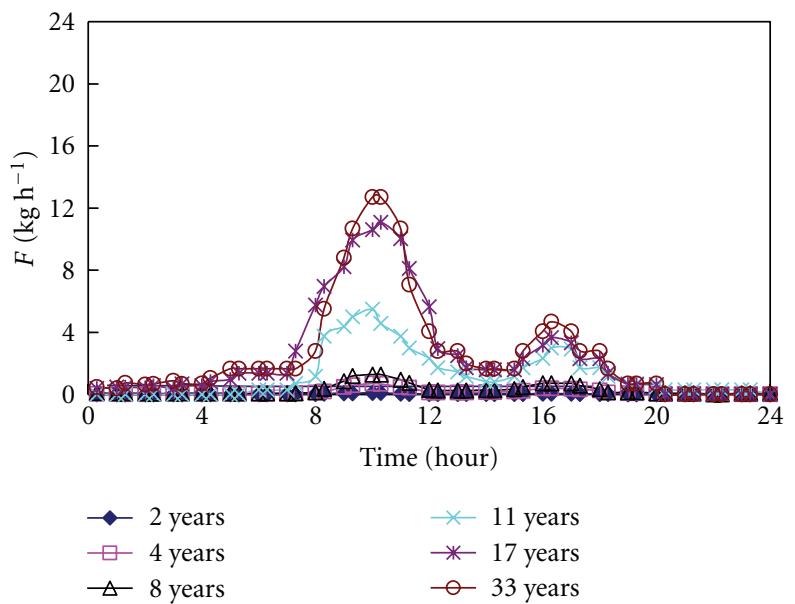

(d)

Figure 2: Diurnal pattern of (a) sap flux density $\left(F_{d}\right)$ and (b) sap flow $(F)$ for 2-, 4-, 8-, 11-, 17-, and 33-year-old mango trees for a typical bright day in October 2002. (c) Sap flux density $\left(F_{d}\right)$ and $(d)$ sap flow $(F)$ are patterns for a typical rainy day.

TABLE 4: Nonlinear least square regression models between tree age and allometric characteristics of Palmer mango trees in Ejura, Ghana.

\begin{tabular}{lcccccc}
\hline Parameter (unit) & \multicolumn{3}{c}{ Power function } & \multicolumn{4}{c}{ Logarithmic function } \\
& $A$ & $B$ & $r^{2}$ & $A$ & $B$ & $r^{2}$ \\
\hline Stem diameter $(\mathrm{cm})$ & 2.438 & 1.037 & 0.965 & 24.918 & -20.615 & 0.925 \\
Tree height $(\mathrm{m})$ & 1.272 & 0.739 & 0.961 & 4.476 & -2.026 & 0.976 \\
Crown diameter $(\mathrm{m})$ & 0.792 & 0.923 & 0.927 & 5.094 & -3.208 & 0.956 \\
Leaf area index & 1.219 & 0.570 & 0.992 & 2.370 & -0.389 & 0.972 \\
$\left(\mathrm{~m}^{2} \mathrm{~m}^{-2}\right)$ & & & & & & \\
\hline
\end{tabular}

$A$ and $B$ are regression parameters and $r^{2}$ is coefficient of determination.

Figure 3 shows the 24-hour integrated values of $F_{d}$ $\left(\mathrm{g} \mathrm{cm}^{-2} \mathrm{~d}^{-1}\right)$ and $F\left(\mathrm{~kg} \mathrm{~d}^{-1}\right)$ for both bright and rainy days. Daily values of $F_{d}$ slightly decreased with increasing tree age. Values observed for 2-, 4-, 8-, and 11-year-old trees, on a bright day, were not significantly different from one another but were different from those of 17- and 33-year-old trees. Flux densities observed for all trees were not significantly different on the rainy day. Daily sap flow showed a marked nonlinear increase for both sky conditions. The values varied from $1.0 \mathrm{~kg} \mathrm{~d}^{-1}$ to $156.6 \mathrm{~kg} \mathrm{~d}^{-1}$ and $0.43 \mathrm{~kg} \mathrm{~d}^{-1}$ to $64.1 \mathrm{~kg} \mathrm{~d}^{-1}$, on bright and rainy days, respectively. A power function fitted between tree age and daily water use yielded a strong association between $F$ and tree age with $r^{2}$ of 0.984 for bright days and 0.981 for the rainy days. Combining the data for the two extreme sky conditions, the percentage of variation in water use explained by tree age was still high $\left(r^{2}=0.873\right)$.

The daytime courses of $F_{d}$ for the three cultivars at age five are shown in Figure 4(a) for DOY 306-310. The observed patterns were similar with Palmer showing the lowest values followed by Haden. Water use by Palmer highly correlates with that of Haden $(r=0.978)$ and with that of Keitt $(r=0.973)$, while Haden and Keitt correlate with $r=0.977$. Daily water use by the three mango varieties from DOY 261 to DOY 275 are shown in Figure 4(b). Sap flow ranged from $6.6 \mathrm{~kg} \mathrm{~d}^{-1}$ to $16.6 \mathrm{~kg} \mathrm{~d}^{-1}\left(\right.$ mean $\left.=11.0 \mathrm{~kg} \mathrm{~d}^{-1}\right)$ for Palmer, $7.6 \mathrm{~kg} \mathrm{~d}^{-1}$ to $18.1 \mathrm{~kg} \mathrm{~d}^{-1}\left(\right.$ mean $\left.=11.5 \mathrm{~kg} \mathrm{~d}^{-1}\right)$ and $8.5 \mathrm{~kg} \mathrm{~d}^{-1}$ to $19.9 \mathrm{~kg} \mathrm{~d}^{-1}\left(\right.$ mean $\left.=12.8 \mathrm{~kg} \mathrm{~d}^{-1}\right)$. For the 15 days of observations presented in Figure 4(b), daily water use by Keitt 


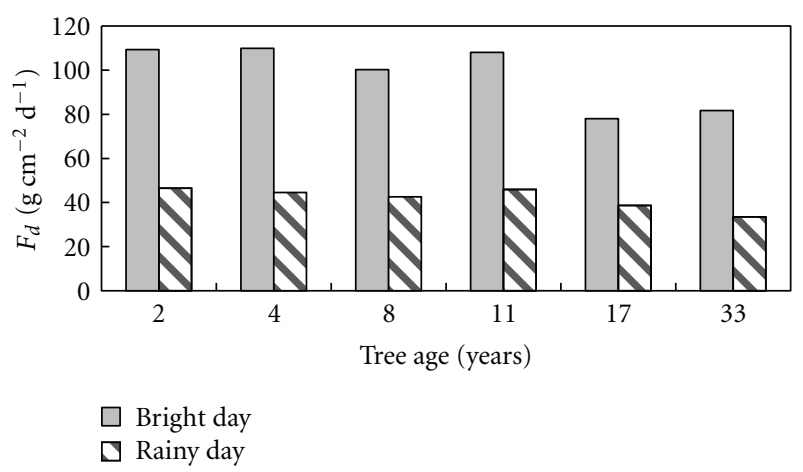

(a)

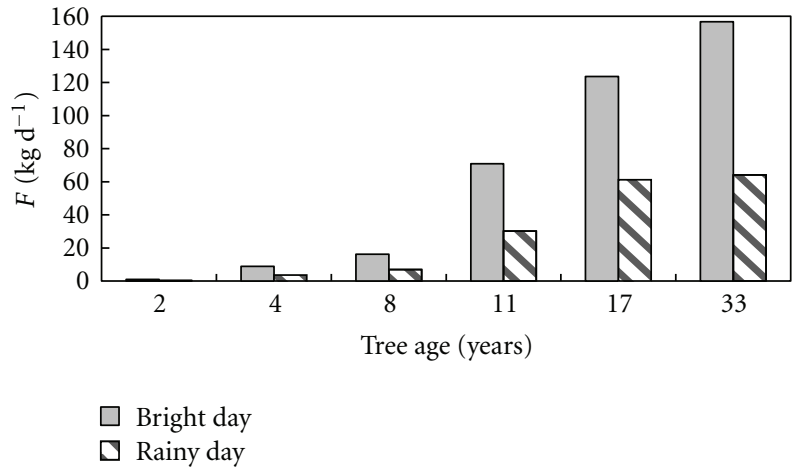

(b)

Figure 3: Influence of tree age on daily (a) sap flux density $\left(F_{d}\right)$ and (b) total sap flow $(F)$ of 2-, 4-, 8-, 11-, 17-, and 33-year-old mango trees for both bright and rainy days in Ejura, Ghana (site I).

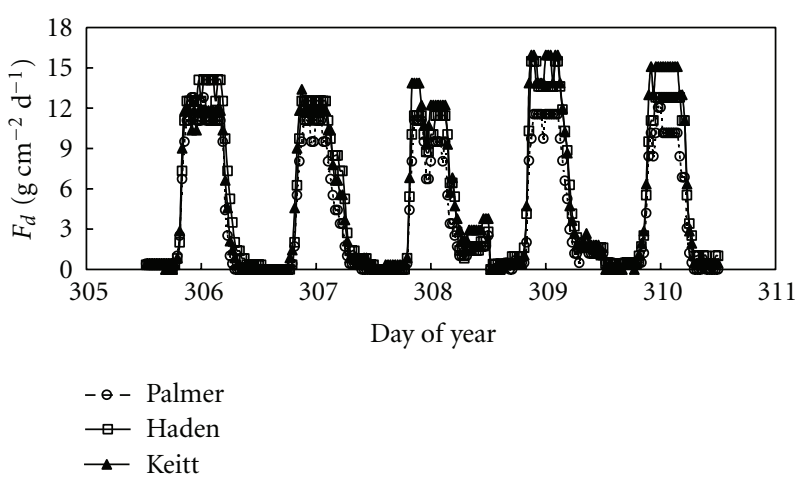

(a)

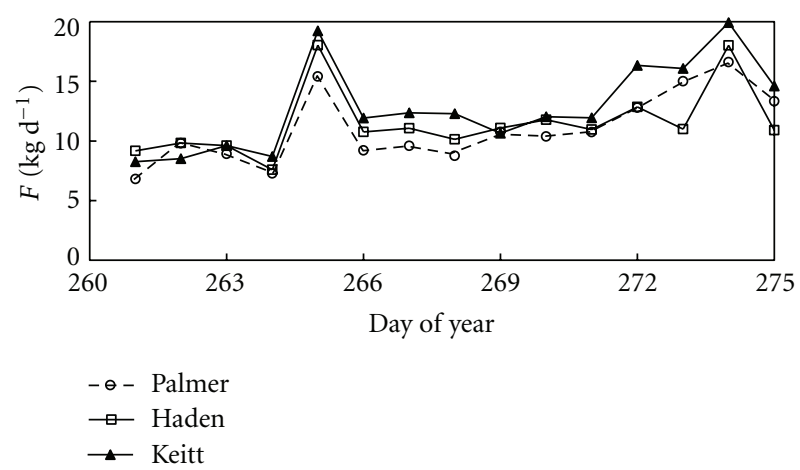

(b)

Figure 4: (a) Diurnal pattern of sap flux density $\left(F_{d}\right)$ of 5-year-old Palmer, Haden, and Keitt during DOY 308-312, and (b) daily sap flow $(F)$ of 5-year-old Palmer, Haden, and Keitt during DOY 261-275, 2002 at Ejura, Ghana (site II).

mostly varied with a CV of $29 \%$, followed closely by Palmer $(\mathrm{CV}=27 \%)$, and Haden $(\mathrm{CV}=25 \%)$. The variation, which is quite similar for the three cultivars, reflects probably the influence of the day-to-day environmental conditions on sap flow.

\section{Discussion and Conclusions}

In mango trees, strong statistical associations were found between age of tree and all other growth parameters investigated. Combining all the age groups, SD explained 92\% of the variations in $\mathrm{TH}, 94 \%$ of the variations in $\mathrm{CD}$, and $93 \%$ of the variations in LAI measured under individual tree canopy. Previous studies have shown similar strong relationships between growth parameters in other species $[15,16]$. The allometric characteristics of the investigated varieties were generally not statistically different except for tree height. The varieties seem to grow somewhat alike but vertical leaf distribution was obviously different for Haden. Furthermore the association between CD and LAI is stronger in Haden than in the other two varieties. A possible reason is that its canopy looks more compact with relatively more leaves, lowest $\mathrm{CD}$ and hence minimum gap fractions, which may translate to higher light interception. Comparing the allometric characteristics between sites I and II for the 4- and 5-yearold palmer showed similar values for all the variables (Table 2). This probably reveals the inherent similarity of both locations.

Although juvenile to mature mango trees were used in this study, the observed trend in $F_{d}$ appears to be consistent with previous work. Daily $F_{d}$ slightly decreased with increasing tree age on both rainy and bright days (Figure 3(a)). Previous work indicates that young mature trees use more water per unit leaf area or sapwood area than old trees of the same species and under similar environmental conditions [9-11]. A recent study showed that differences in $F_{d}$ between trees of different age were greater than those between trees of different species but similar age [17]. The decrease with age in observed $F_{d}$ seems to be in agreement with previous studies as explained by the hydraulic limitation hypothesis (HLH). The HLH proposed that taller/older trees had greater stomatal closure as a result of three interrelated factors [18, 19], (1) increased resistance with increasing hydraulic path length; (2) increased gravitational potential against the ascent of water in taller trees, and (3) maintenance of a speciesspecific minimum water potential in leaves. Decreasing $F_{d}$ with age of mango trees may be due to (1) and (2) above thus leading to reduction in canopy transpiration. In Pinus 
ponderosa trees, whole-tree sap flow per unit leaf area averaged 53\% lower in old trees compared to young trees and mean hydraulic conductance was $63 \%$ lower in old trees than in young trees [20].

A more than $50 \%$ reduction in daily $F_{d}$ was observed on all the gauged trees on a rainy day. Occurrence of precipitation attenuated the diurnal transpiration pattern during the rainfall event while canopy wetness resulting from the rainfall interception reduced $F_{d}$ below the observed value of the bright day. This result is in concordance with Bruijnzeel [21] and Dykes [22] who reported that evaporation in wet tropical climates may be limited by rain events, due to the high frequency of rainfall and high interception evaporation. The vapor pressure deficit, which is considered as the major driving force of transpiration, reduces during rainfall events. Similar observations have been made with regards to the effects of rainfall on water use patterns in a young cashew orchard in the same environment [23]. Although root data were not collected in this study, but previous studies have shown that mango has a long taproot that often branches just below ground level, forming between two and four major anchoring taproots that can reach $6 \mathrm{~m}$ down to the water table. The more fibrous finer roots (feeder roots) are found from between 0 and $1 \mathrm{~m}[2,3]$. Generally, $80-90 \%$ of roots in trees are found within the top $60 \mathrm{~cm}$ of the soil profile, with roots not commonly penetrating deeper than $2 \mathrm{~m}$ [24]. Thus the trees are not water limited during the measurement period (Figure 1), but may require supplementary irrigation to boost yield during dry season (January-March) when flowering and fruiting occur.

Because tree age was highly related to other allometric parameters, age was used as a predictor of daily water use (Figure 3(b)). The strong relationship between tree age and water use in mango tree may be useful to predict the age related effects on plantation water use/requirements. Because of the limitations in other stress indicators such as soil water status, leaf water potential, and stomatal conductance, irrigation scheduling based on direct sap flux density measurements are gaining in importance $[25,26]$. For example, results presented here, with age as a predictor of tree water use, are expected to aid judicious water application to orchard of different age groups, thereby leading to reduction in water wastage and improved crop yield. Sap flux density and total $F$ were not different for the three 5-year-old mangos studied under variety effect experiment. The three varieties (Palmer, Haden, and Keitt) seem to have similar water use strategies at this tender age.

Leaf area index is often assumed to be the most important determinant of differences in transpiration among stands [27]. However, in this study, a higher statistical association $\left(r^{2}=0.94\right)$ was observed between water use and CD than between water use and LAI $\left(r^{2}=0.89\right)$. One possible cause is that the gauged trees are mostly isolated (except for the 33year-old trees) and LAI was measured under the canopy of these individual trees, LAI may be different for closed-canopy plantations. A slight overestimation of LAI is expected for the indirect LAI measurements presented in this study. Other studies have compared the direct and indirect estimates of LAI in forests and concluded that slight overestimation arises in the indirect methods because tree stem and branches account for 4 to $12 \%$ of light interception in forests [16, 28, 29]. In general, the calibrated relations between tree age, allometry, and water use seem very good. As such they can be used for planning of irrigation water needs and water balance estimates of mango plantations in similar environments.

\section{Acknowledgments}

Logistics during data collection was provided through the GLOWA Volta project (Grant number 07GWK01). The first author acknowledges support from Water Research Center of the Delft University of Technology, the Netherlands, during the preparation of this paper.

\section{References}

[1] P. Lu, W. J. Müller, and E. K. Chacko, "Spatial variations in xylem sap flux density in the trunk of orchard-grown, mature mango trees under changing soil water conditions," Tree Physiology, vol. 20, no. 10, pp. 683-692, 2000.

[2] J. F. Morton, "Mango," in Fruits of Warm Climates, J. F. Morton and F. L. Miami, Eds., pp. 221-237, Creative Resources Systems, Bixby, Okla, USA, 1987.

[3] S. Rehm and G. Espig, The Cultivated Plants of the Tropics and Subtropics, Josef Margraf, Illschwang, Germany, 1991.

[4] P. Lu and E. K. Chacko, "Xylem sap flow measurement in mango trees," Acta Horticulturae, vol. 455, pp. 339-350, 1997.

[5] J. Leonardi, S. J. Blaikie, W. J. Muller, N. Steele Scott, and E. K. Chacko, "Effect of cincturing and chemical treatments on growth, flowering and yield of mango (Mangifera indica L.) cv. Kensington pride," Australian Journal of Experimental Agriculture, vol. 39, no. 6, pp. 761-770, 1999.

[6] B. Schaffer, A. W. Whiley, and J. H. Crane, "Mango," in Handbook of Environmental Physiology of Fruit Crops. Sub-tropical and Tropical Crops, B. Schaffer and P. C. Andersen, Eds., vol. 2, pp. 165-197, CRC Press, Boca Raton, Fla, USA, 1994.

[7] P. Lu and E. K. Chacko, "Evaluation of Granier's sap flow meter in mango (Mangifera indica L.) trees," Agronomie, vol. 18, pp. 461-471, 1998.

[8] A. González, P. Lu, and W. Müller, "Effect of pre-flowering irrigation on leaf photosynthesis, whole-tree water use and fruit yield of mango trees receiving two flowering treatments," Scientia Horticulturae, vol. 102, no. 2, pp. 189-211, 2004.

[9] J. C. Domec and B. L. Gartner, "Cavitation and water storage capacity in bole xylem segments of mature and young Douglas-fir trees," Trees, vol. 15, no. 4, pp. 204-214, 2001.

[10] N. McDowell, H. Barnard, B. J. Bond et al., "The relationship between tree height and leaf area: sapwood area ratio," Oecologia, vol. 132, no. 1, pp. 12-20, 2002.

[11] M. G. Ryan, B. J. Bond, B. E. Law et al., "Transpiration and whole-tree conductance in ponderosa pine trees of different heights," Oecologia, vol. 124, no. 4, pp. 553-560, 2000.

[12] P. G. Oguntunde and A. M. Oguntuase, "Influence of environmental factors on the sap flux density of mango trees under rain-fed cropping systems in West Africa," International Journal of Plant Production, vol. 1, no. 2, pp. 86-95, 2007.

[13] A. Granier, "Evaluation of transpiration in a Douglas-fir stand by means of sap flow measurements," Tree Physiology, vol. 3, pp. 309-320, 1987.

[14] P. G. Oguntunde, A. E. Ajayi, J. Friesen, N. van de Giesen, and P. L. G. Vlek, "Seasonal variation of temporal patterns 
of water flux in a cashew orchard under sub-humid tropical conditions," Journal of Crop Improvement, vol. 25, no. 5, pp. 504-520, 2011.

[15] C. L. Brack, M. P. Dawson, and A. M. Gill, "Bark, leaf and sapwood dimensions in Eucalyptus," Australian Forestry Research, vol. 1, pp. 1-7, 1985.

[16] R. A. Vertessy, R. G. Benyon, S. K. O’Sullivan, and P. R. Gribben, "Relationships between stem diameter, sapwood area, leaf area and transpiration in a young mountain ash forest," Tree Physiology, vol. 15, no. 9, pp. 559-567, 1995.

[17] G. W. Moore, B. J. Bond, J. A. Jones, N. Phillips, and F. C. Meinzer, "Structural and compositional controls on transpiration in 40- and 450-year-old riparian forests in Western Oregon, USA," Tree Physiology, vol. 24, no. 5, pp. 481-491, 2004.

[18] M. G. Ryan and B. J. Yoder, "Hydraulic limits to tree height and tree growth: what keeps trees from growing beyond a certain height?" BioScience, vol. 47, no. 4, pp. 235-242, 1997.

[19] M. G. Ryan, N. Phillips, and B. J. Bond, "The hydraulic limitation hypothesis revisited," Plant, Cell and Environment, vol. 29, no. 3, pp. 367-381, 2006.

[20] R. M. Hubbard, B. J. Bond, and M. G. Ryan, "Evidence that hydraulic conductance limits photosynthesis in old Pinus ponderosa trees," Tree Physiology, vol. 19, no. 3, pp. 165-172, 1999.

[21] L. A. Bruijnzeel, "Predicting the hydrological impact of land cover transformation in the humid: the need for integrated research," in Amazonia Deforestation and Climate, J. H. C. Gash, C. A. Nobre, J. M. Roberts, and R. L. Victoria, Eds., pp. 15-55, John Wiley \& Sons, Chichester, UK, 1996.

[22] A. P. Dykes, "Rainfall interception from a lowland tropical rainforest in Brunei," Journal of Hydrology, vol. 200, no. 1-4, pp. 260-279, 1997.

[23] P. G. Oguntunde and N. van de Giesen, "Water flux measurement and prediction in young cashew trees using sap flow data," Hydrological Processes, vol. 19, no. 16, pp. 3235-3248, 2005.

[24] I. S. E. Bally, "Mangifera indica (mango), ver. 3.1," in Species Profiles for Pacific Island Agroforestry, C. R. Elevitch, Ed., Permanent Agriculture Resources (PAR), Holualoa, Hawaii, USA, 2006.

[25] H. G. Jones, "Irrigation scheduling: advantages and pitfalls of plant-based methods," Journal of Experimental Botany, vol. 55, no. 407, pp. 2427-2436, 2004.

[26] K. Steppe, D. J. W. De Pauw, and R. Lemeur, "A step towards new irrigation scheduling strategies using plant-based measurements and mathematical modelling," Irrigation Science, vol. 26, no. 6, pp. 505-517, 2008.

[27] J. D. Hewlett, Principle of Forest Hydrology, University of Georgia Press, Athens, Ga, USA, 1982.

[28] H. H. Neumann, G. Den Hartog, and R. H. Shaw, "Leaf area measurements based on hemispheric photographs and leaflitter collection in a deciduous forest during autumn leaf-fall," Agricultural and Forest Meteorology, vol. 45, no. 3-4, pp. 325$345,1989$.

[29] J. W. Chason, D. D. Baldocchi, and M. A. Huston, "A comparison of direct and indirect methods for estimating forest canopy leaf area," Agricultural and Forest Meteorology, vol. 57, no. 1-3, pp. 107-128, 1991. 

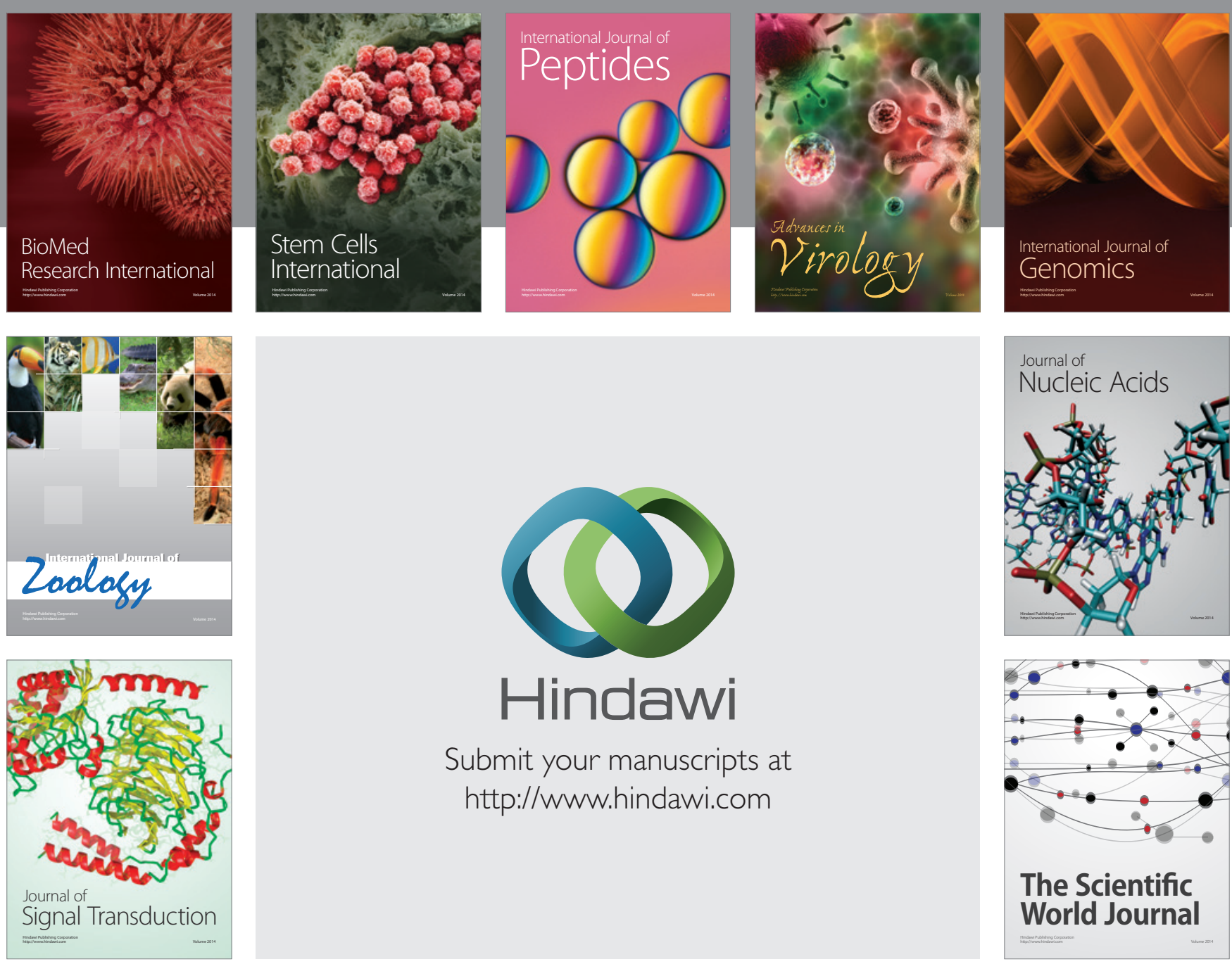

Submit your manuscripts at

http://www.hindawi.com
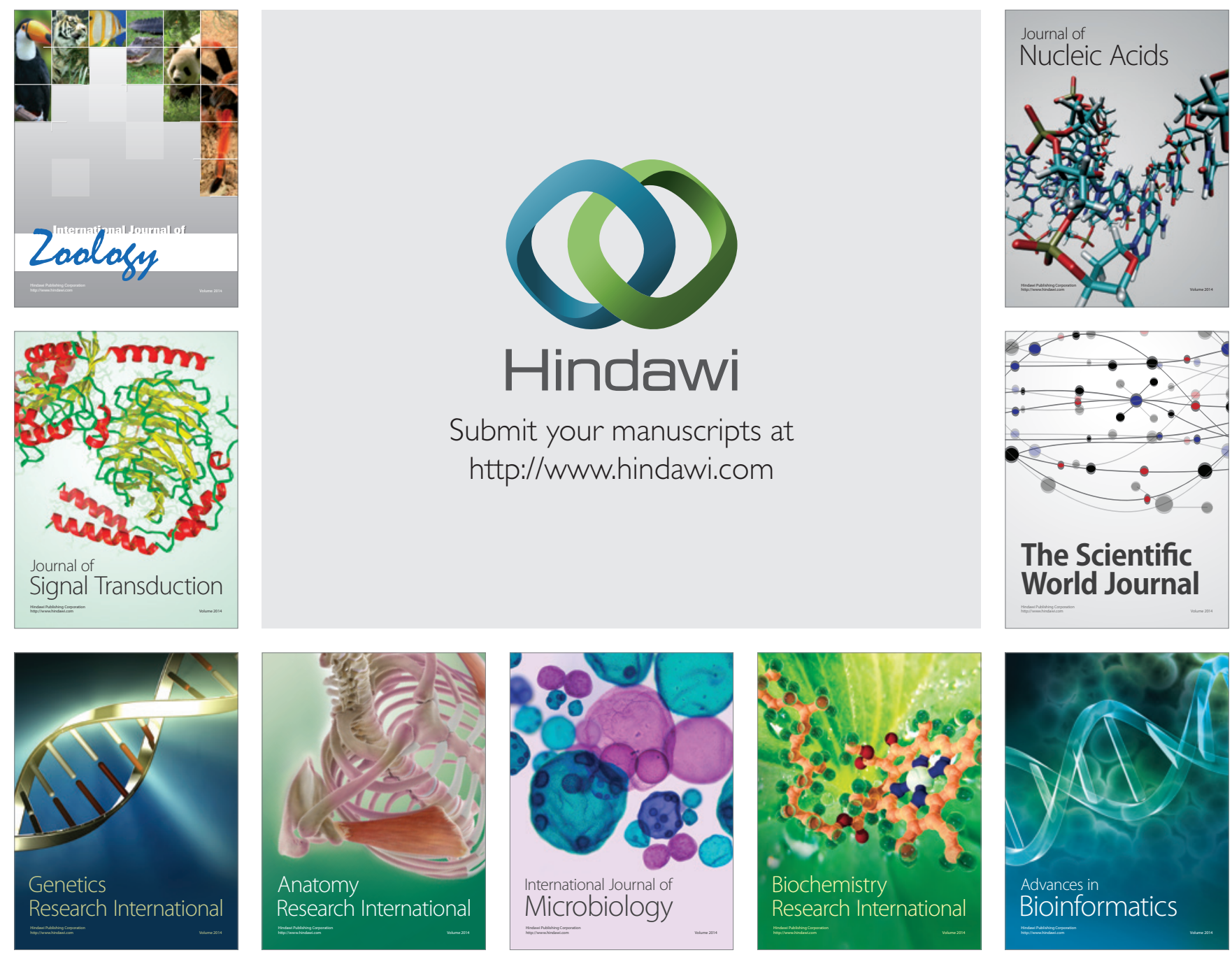

The Scientific World Journal
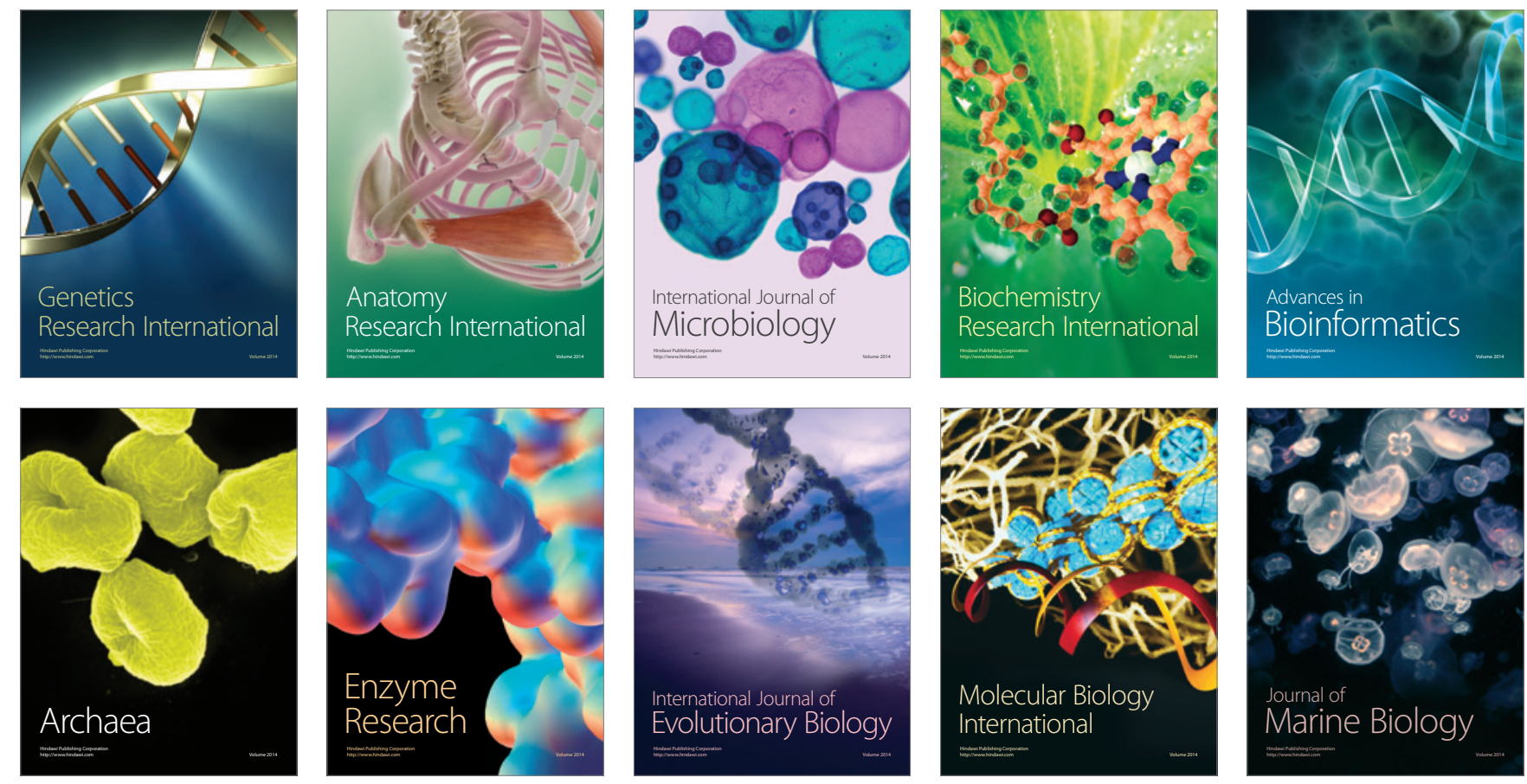